\title{
Prognostic Significance of KAI-1 and Survivin Expressions in Ovarian Epithelial Carcinomas
}

\author{
Ju-Han Lee, M.D., Suk-Min Lee, M.D. and Jong-Sang Choi, M.D. \\ Department of Pathology, College of Medicine, Korea University, Seoul, Korea
}

Purpose: The purpose of this study was to evaluate the expressions of KAl-1 and survivin, and to investigate their correlation with the clinical stage and survival rate of patients with ovarian carcinomas.

Materials and Methods: The expressions of survivin and KAl-1 were immunohistochemically determined in 54 serous and mucinous ovarian adenocarcinomas and borderline malignancy tumors. 10 of the 54 cases were also analyzed for the expressions of survivin and $\mathrm{KAl}-1$ using western blot.

Results: The down-regulation of the expression of KAI-1 was observed by immunohistochemical staining (IHC) in $53.7 \%$ of the ovarian cancers, and a negative reaction in $50 \%$ by the western blot analysis. From the IHC, the survivin expression was positive and strongly positive in 51.9 and $18 \%$ of the ovarian cancers,

\section{서 론}

난소 종양은 부인과 암 중에서 사망률이 가장 높은 질환 으로 그 중 장액성 선암(serous adenocarcinoma)과 점액성 선 암(mucinous adenocarcinoma) 등 상피세포에서 유래되는 종 양은 전체 난소 종양의 60 70\%를 차지한다(1). 최근 분자 생물학의 발전으로 기존의 난소 종양의 예후를 결정하는 요인이었던 환자의 나이, 병기, 조직학적 유형, 조직학적 분 화도 및 치료방법 등 이외에도 다양한 예후 인자에 대한 연구가 이루어지고 있는데, 가족력을 가진 난소암에서 $\mathrm{BRCA}$ 유전자의 변이가 확인되고 있고(2), 난소종양의 진행 에 HER-2/neu, myc, ras, p53 유전자 등이 관여하는 것으로 밝혀졌다 $(3,4)$. 임상적으로는 CA 125 등이 종양 표지자로 이용되고 있으나, 난소 종양의 예후를 미리 예측할 수 있는 보다 높은 민감도와 특이도를 보이는 객관적인 지표가 계

Correspondence: Jong-Sang Choi, Department of Pathology, College of Medicine, Korea University, Seoul 136-705, Korea. (Tel) 02-920-6145, (Fax) 02-953-3130, (E-mail) jongchoi@kumc. or.kr

Received January 24, 2003, Accepted July 8, 2002 respectively. From the western blot analysis, $10 \%$ of the ovarian cancer showed positive reactions. The downregulation of the $\mathrm{KAl}-1$ expression was significantly correlated with the clinical stage $(p=0.001)$ and disease free survival rate $(p<0.001)$, but not with the histological type. The expression of survivin was not correlated with the clinical stage or histological type. However, the patients with a negative survivin expression had a significantly longer disease survival rate than those with a strong positive expression.

Conclusion: The down- and up-regulation of the KAl-1 and survivin, respectively, might be independent prognostic factors in human ovarian carcinomas. (Cancer Research and Treatment 2003;35:323-329)

Key Words: Ovary neoplasm, Survivin, KAl-1

속해서 연구되고 있는 실정이다.

KAI-1 유전자는 염색체 $11 \mathrm{p} 11.2$ 에 위치하는 전립선암의 전이 억제 유전자로 처음보고되었다(5). KAI-1 단백은 267 개의 아미노산으로 구성된 세포 표면 당단백으로 신호 전 달 체계에 중요한 역할을 할 뿐 아니라, 세포 성장, 세포 분 화, 세포의 운동성 등을 조절하여 종양의 진행과 전이에서 중요한 역할을 하고 있는 것으로 보고되고 있는데, 전립선 암 뿐 아니라 췌장암, 비소세포성 폐암, 방광암, 유방암 등 의 진행에도 관여하는 것으로 알려져 있다(6 10).

Survivin은 염색체 $17 \mathrm{q} 25$ 에 위치하는 $14.7 \mathrm{~kb}$ 크기의 유전 자로, survivin 단백은 세포자멸사를 억제하고 세포 분열을 조절하는 것으로 알려져 있다 $(11 \sim 13)$. 대부분의 암종에서 암종의 종류나 분화 정도에 상관 없이 survivin 단백이 과발 현되는 것으로 보고되고 있고, 특히 직장암이나, 비소세포 성 폐암, 유방암 등에서 survivin의 과발현을 보이는 예들이 생존율이 더 낮다는 보고들이 있어 예후인자로서의 중요성 에 대한 연구가 계속되고 있다(14 16).

본 연구는 상피성 난소 암종 중 가장 흔한 암종인 장액성 악성 종양과 점액성 악성 종양에서 survivin과 KAI-1 단백의 발현 여부의 정도를 면역화학 염색과 western blot을 이용하 여 비교 관찰하였고, KAI-1 단백 발현의 감소 또는 소실과 
survivin 단백의 발현이 조직학적 유형, 임상 병기 및 환자의 생존 기간에 따라 어떠한 변화를 보이는지 알아보고자 하 였다.

\section{재료 및 방법}

\section{1) 연구대상}

1996년 6월부터 2002년 3월까지 고려대학교 안암병원, 구로병원, 삼성제일병원 및 인천길병원에서 상피성 난소 종양으로 수술한 예 중 파라핀 포매 조직의 보관 상태가 양호하여 면역조직화학 염색이 가능하고, 생존 여부가 확 인된 54예를 대상으로 하였다. 상피성 난소암종 중 가장 대 표적인 장액성 종양과 점액성 종양을 비슷한 분포가 되게 하였다. 이 중 동결 보관된 신선 조직이 있는 10 예에서 Western blot 분석을 시행하였다. 54예는 장액성 종양이 26 예, 점액성 종양이 28예였고, 장액성 종양 26예 중 25예가 장액성 선암종이고 1 예가 경계영역성 장액성 종양이었다. 점액성 종양 28 예 중 24 예가 점액성 선암종이었고 4 예가 경 계영역성 점액성 종양이었다. 임상 기록지와 병리 기록지 를 중심으로 환자의 연령, 병기 등을 확인하였고, 전화를 통 해 생존 여부 및 사망한 날짜를 확인하였다. 환자의 평균 추적기간은 24.3개월(범위 6 72개월)이었고, 54예 중 9예 (16.7\%)가 사망하였는데, 이들 9예는 장액성 선암종이 5예 였고, 점액성 선암종이 4 예였다. 54 예의 평균 나이는 46.7 세 (범위: 16 74세)였고, 장액성 종양과 점액성 종양의 평균 나이는 각각 51.9세와 41.8세로 장액성 종양이 더 높았다. FIGO 분류법(17)에 의해 54예의 임상병기는 I기 24예, II기 11예, III기 19예였고, 장액성 종양은 I기 4예, II기 9예, III기 13 예였으며, 점액성 종양은 I기 20예, II기 2예, III기 6예였 다. Western blot을 시행한 10예는 장액성 선암종 4예, 경계 영역성 장액성 종양 1 예, 점액성 선암종 3 예, 경계영역성 점 액성 종양 2 예였다. 10 예의 임상병기는 I기 4 예, II기 1 예, III기 5 예였다.

\section{2) 연구방법}

(1) 면역조직화학 염색: KAI-1 단백(Santa Cruz, Santa Cruz, CA)과 survivin 단백(Santa Cruz)에 대한 면역조직화학 염색을 시행하였다. $10 \%$ 중성 완충 포르말린에 고정한 후 제작한 파라핀 포매조직을 $4 \mu \mathrm{m}$ 두께로 박절하여 xylene으 로 2회 탈파라핀하고 에탄올로 처리한 후 증류수로 함수시 켰다. 함수시킨 절편을 시트르산염 완충액(pH 6.0)에 15분 간 처리한 후 $3 \%$ 과산화수소로 내인성 과산화효소의 작용 을 억제시켰다. Tris 완충용액으로 수세한 후 일차항체로 survivin $(1: 100), \mathrm{KAI}-1$ (1:100)을 이용하여 실온에서 1시
간 동안 반응시킨 후 Tris 완충용액으로 수세하였다. Biotin 과 결합된 2차항체(Zymed, South San Francisco, CA)에 30분 간 1회 반응시킨 후 Tris 완충용액으로 수세하고 streptavidin 과 peroxidase가 결합된 용액에 30 분간 처리하였다. 이를 diaminobenzidine (DAB)로 발색시킨 다음 Mayer's hematoxylin으로 대조염색하고 봉입하였다.

판독방법은 2 명의 병리 의사가 함께 판독하여 KAI- 1 단 백은 세포질에 갈색으로 염색되면 양성으로 판정하였고, survivin 단백은 핵이나 세포질에 갈색으로 염색되면 양성 으로 판정하였다. 양성 세포의 양적 평가는 양성 세포가 없 거나 5\% 미만인 경우는 음성, 양성 세포가 6 50\%인 경우 는 $1+$ (양성), $51 \%$ 이상인 경우는 $2+$ (강양성)로 분류하 였다.

(2) Western blot analysis: $-80^{\circ} \mathrm{C}$ 에 보관된 동결된 암 조 직을 분쇄시킨 후 $1 \mathrm{ml}$ lysis buffer $(150 \mathrm{mM} \mathrm{NaCl}, 20 \mathrm{mM}$ Tris pH 8.0, 1\% (V/V) Nonidet P-40, $1 \mathrm{mM}$ phenylmethylsulfonyl fluoride, $10 \mathrm{\mu g} / \mathrm{ml}$ leupeptin)을 이용, 시료를 분해(lysis)시켰 다. $13,000 \mathrm{rpm}, 4^{\circ} \mathrm{C}$ 조건하에서 원심분리를 통해 찌꺼기를 제거하고, Laemmli sample buffer를 넣고 5 분 동안 끓인 후 정제된 난소암 단백질 약 20g을 10\% SDS polyacrylamide gel에서 전기영동을 시킨 후 nitrocellulose membrane으로 단 백질을 전이시켰다. Tris buffered saline에 녹아있는 5\% skimmed milk를 이용 membrane을 1시간 동안 상온에서 차 단시켰다. 일차항체인 KAI-1 단백(Santa Cruz, Santa Cruz, $\mathrm{CA}$ )과 survivin 단백(Santa Cruz)에 대한 각각의 항체를 1 : 500 의 비율로 $5 \%$ skimmed milk로 희석시킨 후 상온에서 1 시간 동안 반응시켰다. 1차 항체 반응 후 PBS/ Tween-20을 이용하여 10 분씩 3 회 씻어 준 후 $5 \%$ skimmed milk에 1 : 1,500 으로 희석시킨 2 차 항체와 반응시켰고 위와 동일한 방 법으로 Membranes을 씻어주고 chemoluminescene (ECL; Amersham, $\mathrm{UK}$ )를 이용 모든 단백질을 확인하였다. 동일 Membrane을 이용 2개의 단백질을 동시에 확인하기 위해 $0.1 \mathrm{M}$ glycerine $\mathrm{pH}$ 2.9을 이용 Membrane을 30분 동안 반응시 킨 후 PBS/Tween-20으로 3회 씻어주고 차단 단계부터 위에 서 언급한 과정을 재실행하였다.

(3)통계 분석: 통계학적 분석은 SAS 8.0 program과 SPSS 9.0 program을 이용하였다. 면역조직화학 염색 결과와 조직 학적 분류 및 임상병기와의 비교는 Cochran-Mantel-Haenzel test로 검정하여 $\mathrm{p}<0.05$ 인 경우를 통계학적으로 유의한 것 으로 판정하였다. 생존율은 Kaplan-Meier 법으로 산출하였 으며, 생존곡선은 Log-rank test로 비교하여 $\mathrm{p}$ 값이 0.05 이하 를 유의한 것으로 판정하였다. 
Table 1. KAI-1 expression in immohistochemistry

\begin{tabular}{|c|c|c|c|c|}
\hline & Negative & $1+$ & $2+$ & $\mathrm{p}$ value \\
\hline Histologic type & & & & $>0.05$ \\
\hline Serous carcinoma \& borderline serous tumor & $5(9.3 \%)$ & $11(20.3 \%)$ & $10(18.5 \%)$ & \\
\hline Mucinous carcinoma \& borderline mucinous tumor & $4(7.4 \%)$ & $9(16.7 \%)$ & $15(27.8 \%)$ & \\
\hline Clinical stage & & & & 0.0001 \\
\hline Stage I & $2(3.7 \%)$ & $4(7.4 \%)$ & $18(33.3 \%)$ & \\
\hline Stage II & $1(1.9 \%)$ & $5(9.3 \%)$ & $5(9.3 \%)$ & \\
\hline Stage III & $6(11.1 \%)$ & $11(20.3 \%)$ & $2(3.7 \%)$ & \\
\hline Total number & $9(16.7 \%)$ & $20(37.0 \%)$ & $25(46.3 \%)$ & \\
\hline \multicolumn{5}{|l|}{ Clinical stage according to histologic type } \\
\hline serous adenocarcinoma \& borderline serous tumor & & & & 0.0001 \\
\hline Stgae I & $0(0.0 \%)$ & $0(0.0 \%)$ & $4(15.4 \%)$ & \\
\hline Stage II & $1(3.8 \%)$ & $4(15.4 \%)$ & $4(15.4 \%)$ & \\
\hline Stage III & $4(15.4 \%)$ & $7(26.9 \%)$ & $2(7.7 \%)$ & \\
\hline Total number & $5(19.2 \%)$ & $11(42.3 \%)$ & $10(38.5 \%)$ & \\
\hline Mucinous adenocarcinoma \& borderline mucinous tumor & & & & 0.0001 \\
\hline Stage I & $2(7.15 \%)$ & $4(14.3 \%)$ & $14(50.0 \%)$ & \\
\hline Stage II & $0(0.0 \%)$ & $1(3.6 \%)$ & $1(3.6 \%)$ & \\
\hline Stage III & $2(7.15 \%)$ & $4(14.3 \%)$ & $0(0.0 \%)$ & \\
\hline Total number & $4(14.3 \%)$ & $9(32.1 \%)$ & $15(53.6 \%)$ & \\
\hline
\end{tabular}

$1+: 5 \sim 50 \%$ positive tumor cells, $2+:>51 \%$ positive tumor cells, $\mathrm{p}$ value; Cochran-Mantel-Haenzel test

Table 2. Survivin expression in immohistochemistry

\begin{tabular}{|c|c|c|c|c|}
\hline & Negative & $1+$ & $2+$ & $\mathrm{p}$ value \\
\hline Histologic type & & & & $>0.05$ \\
\hline Serous carcinoma \& borderline serous tumor & $7(12.9 \%)$ & $13(24.1 \%)$ & $6(11.1 \%)$ & \\
\hline Mucinous carcinoma \& borderline mucinous tumor & $9(16.7 \%)$ & $15(27.8 \%)$ & $4(7.4 \%)$ & \\
\hline Clinical Stage & & & & $>0.05$ \\
\hline Stage I & $9(16.7 \%)$ & $9(16.7 \%)$ & $6(11.1 \%)$ & \\
\hline Stage II & $2(3.7 \%)$ & $9(16.7 \%)$ & $0(0.0 \%)$ & \\
\hline Stage III & $5(9.2 \%)$ & $10(18.5 \%)$ & $4(7.4 \%)$ & \\
\hline Total number & $16(29.6 \%)$ & $28(51.9 \%)$ & $10(18.5 \%)$ & \\
\hline \multicolumn{5}{|l|}{ Clinical stage according to histologic type } \\
\hline serous adenocarcinoma \& borderline serous tumor & & & & $>0.05$ \\
\hline Stgae I & $1(3.8 \%)$ & $1(3.8 \%)$ & $2(7.7 \%)$ & \\
\hline Stage II & $2(7.7 \%)$ & $7(26.9 \%)$ & $0(0.0 \%)$ & \\
\hline Stage III & $4(15.4 \%)$ & $5(19.3 \%)$ & $4(15.4 \%)$ & \\
\hline Total number & $7(26.9 \%)$ & $13(50.0 \%)$ & $6(23.1 \%)$ & \\
\hline Mucinous adenocarcinoma \& borderline mucinous tumor & & & & $>0.05$ \\
\hline Stage I & $8(28.6 \%)$ & $8(28.6 \%)$ & $4(14.3 \%)$ & \\
\hline Stage II & $0(0.0 \%)$ & $2(7.1 \%)$ & $0(0.0 \%)$ & \\
\hline Stage III & $1(3.5 \%)$ & $5(17.9 \%)$ & $0(0.0 \%)$ & \\
\hline Total number & $9(32.1 \%)$ & $15(53.6 \%)$ & $4(14.3 \%)$ & \\
\hline
\end{tabular}

1+: $5 \sim 50 \%$ positive tumor cells, $2+:>51 \%$ positive tumor cells, $\mathrm{p}$ value; Cochran-Mantel-Haenzel test 


\section{결 과}

\section{1) 면역조직화학 염색 소견}

(1) KAI-1 단백 발현 양상: KAI-1 단백이 2+ (강양성)으 로 발현되는 경우는 25 예(46.3\%)였고, $1+$ (양성)으로 감소 되는 경우는 20 예(37.0\%)였으며, 음성으로 발현되지 않는 경우는 9 예(16.7\%)로 장액성 종양과 점액성 종양 사이의 조 직학적 분류에 따른 KAI-1 단백 발현의 통계학적 차이는 관찰되지 않았으나 $(\mathrm{p}>0.05)$, 임상병기가 I기에서 III기로 진 행될수록 KAI-1 단백은 발현되지 않는 양상을 보였으며, 이 는 통계학적으로 유의하였다 $(\mathrm{p}=0.0001)$. 종양별 임상병기에 따른 KAI-1 발현 양상을 살펴보면, 장액성 종양과 점액성 종양에 따른 각각 임상병기가 높아질수록 통계학적으로 유 의하게 발현이 되지 않는 양상을 보였다( $\mathrm{p}=0.0001)$ (Table 1 , Fig. 1)

(2) Survivin 단백 발현 양상: Survivin 단백이 2+ (강양 성)으로 발현되는 경우는 총 10 예(18.5\%)였고, $1+$ (양성)으 로 발현되는 경우는 28예(51.9\%)였으며, 음성으로 발현되지

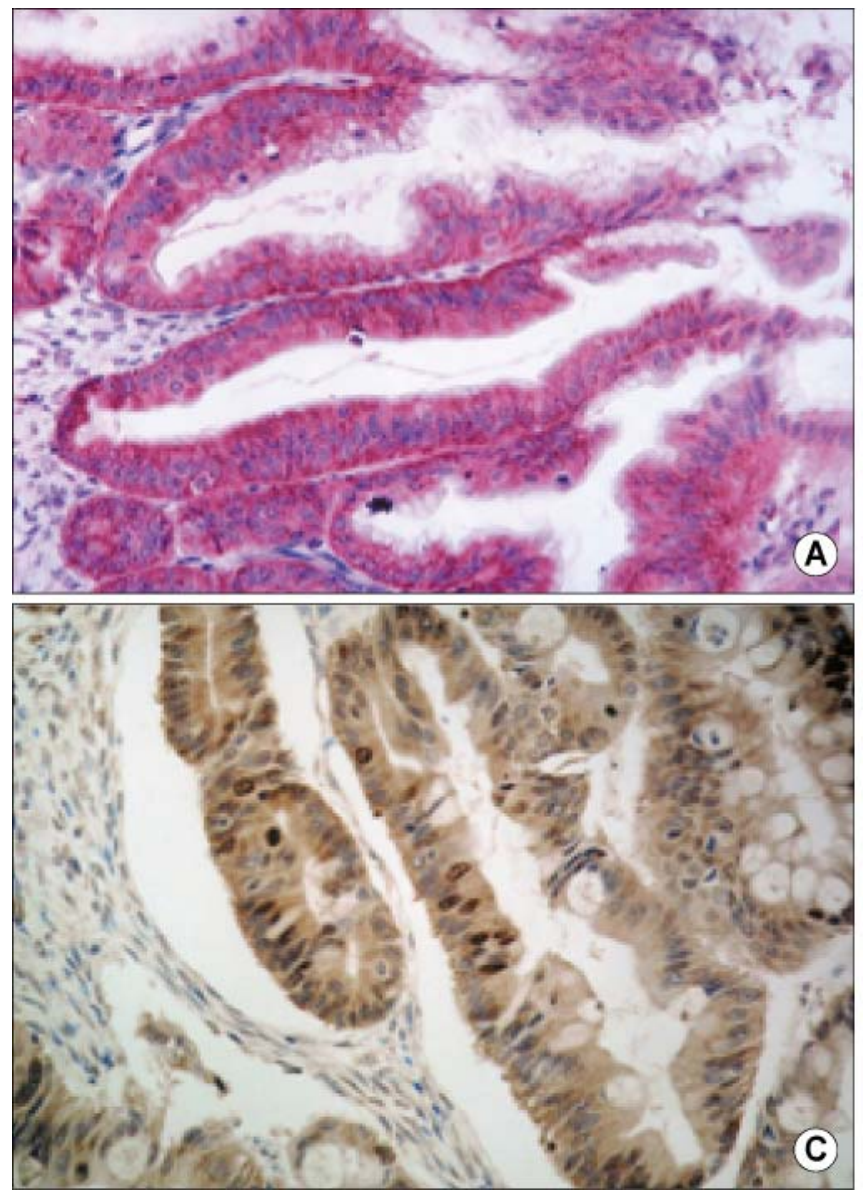

않는 경우는 16 예(29.6\%)였다. Survivin 단백 발현은 조직학 적 분류나 임상병기에 따른 차이가 관찰되지 않았다 $(\mathrm{p}>$ 0.05). 종양별 임상병기에 따른 survivin 발현 양상도 특별한 차이가 관찰되지 않았다 $(\mathrm{p}>0.05)($ Table 2, Fig. 1)

\section{2) 생존분석}

$\mathrm{KAI}-1$ 에 대한 생존곡선 분석상 생존율은 강양성군, 양성 군, 음성군 순으로 감소하는 양상을 보였고, 강양성으로 발 현된 군이 양성과 음성으로 발현이 감소된 군에 비해 유의 하게 생존율이 높았다 $(\mathrm{p}<0.001, \mathrm{p}<0.01$, Fig. 2). Survivin 단 백에 대한 생존곡선 분석상 생존율은 음성군, 양성군, 강양 성군순으로 감소하는 경향을 보였고, 이중 강양성으로 발 현된 군은 음성인 군에 비해 유의하게 생존율이 감소하였 다 $(\mathrm{p}=0.05)$.

\section{3) Western blot analysis}

(1) KAI-1 단백 발현 양상: KAI-1 단백이 발현되는 경우는 5 예로 장액성 선암종 3 예, 점액성 선암종 1 예, 경계영역성 점액성 종양 1 예였다. 발현이 되지 않는 경우는 5 예로 장액

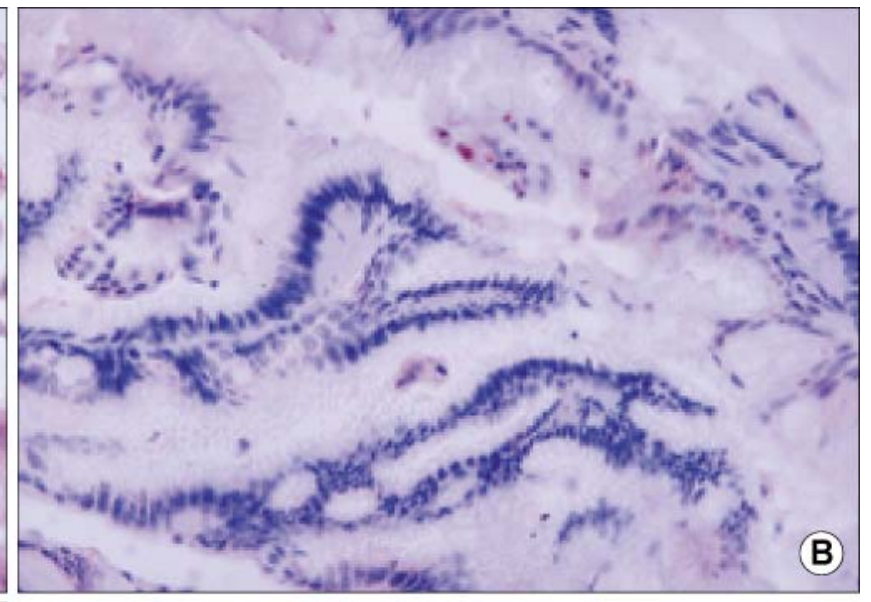

Fig. 1. Microphotograph of immunohistochemical staining of KAI-1 and survivin protein. (A) Strong positive expression of KAI-1 protein for cytoplasm and membrane of mucinous adenocarcinoma $(\times 200)$. (B) Negative expression of KAI-1 protein for cytoplasm and negative expression of mucinous adenocarcinoma $(\times 200)$. (C) Strong positive expression of survivin protein for nucleus and cytoplasm of mucinous adenocarcinoma $(\times 400)$. 
성 선암종 1 예, 경계영역성 장액성 종양 1 예, 점액성 선암종 2 예, 경계영역성 점액성 종양 1 예였다. 상피성 난소 암종의 종류에 따른 KAI-1 단백 발현의 통계학적 차이는 관찰되지 않았다(p>0.05). 임상병기에 따른 KAI-1 단백 발현 양상을 보면 I기 4예 중 2예가 발현되지 않았고, II기 1예가 발현되지 않았으며, III기 5예 중 2예가 발현되지 않았다(Table 3, Fig. 3).

(2) Survivin 단백 발현 양상: Survivin 단백은 1예의 장액 성 선암종에서 발현되었고, 9예에서는 발현되지 않았다. 발 현된 1예의 임상병기는 III기였다(Table 3, Fig. 3).

\section{4) KAI-1 단백과 survivin 단백의 혼합군}

Survivin 단백과 KAI-1 단백의 발현 양상을 이용하여 크게

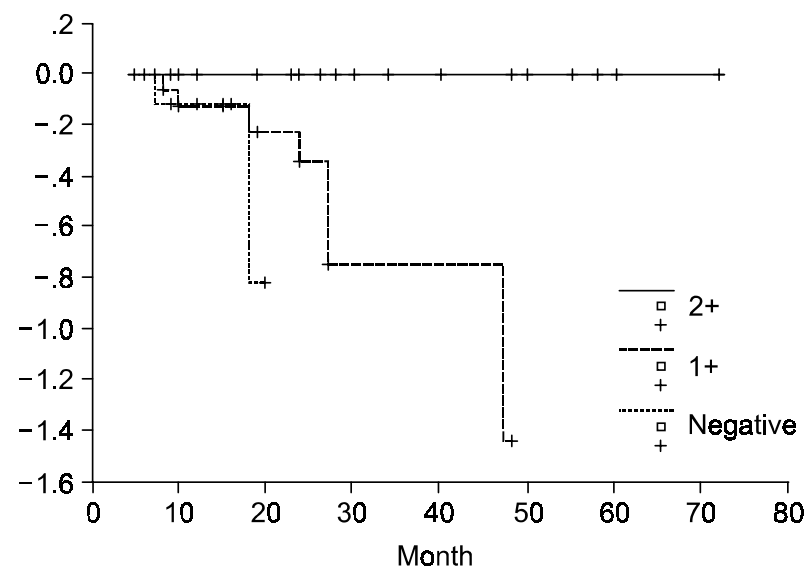

Fig. 2. Survival analysis according to KAI-1 expression.

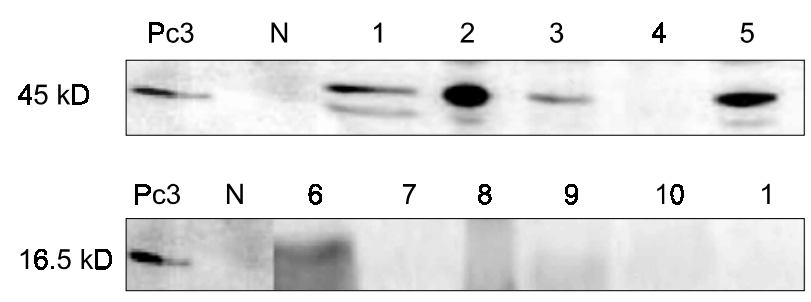

Fig. 3. KAI-1 and survivin expression in western blot. Upper lane shows western blot of KAI-1 protein. Lane No 1, 2, 3, 5. show positive reaction and No 4 . shows negative reaction. Lower lane shows western blot of survivin protein. Lane No 6. shows positive reaction, but others show negative reaction. Pc 3: Human prostatic cancer cells (Positive control), N: Negative control, Sample Number 1: 01-10544 mucinous adenocarcinoma, 2: 98-7335 serous adenocarcinoma, 3: 98182 serous adenocarcinoma, 4: 98-14492 mucinous adenocarcinoma, 5: 96-6665 serous adenocarcinoma, 6: 99-16566 serous adenocarcinoma, 7: 01-13829 serous tumor, borderline malignancy, 8: 98-12954 mucinous tumor, borderline malignancy, 9: 00-10961 mucinous adenocarcinoma, 10: 01-11175 mucinous tumor, borderline malignancy.
4개의 군으로 나누었다. A군은 survivin 단백이 양성이거나 음성이면서 KAI-1 단백은 강양성인 예들, B군은 survivin 단 백은 강양성으로 발현되고 $\mathrm{KAI}-1$ 단백도 강양성인 예들, C 군은 survivin 단백이 양성이거나 음성이면서 KAI-1 단백은 감소하는 예들, D군은 survivin 단백이 강양성으로 발현되 고, KAI-1 단백은 감소하는 예들로 나누었다. A군이 19예, $\mathrm{B}$ 군이 6예, $\mathrm{C}$ 군이 25 예, D군이 4예였다. 종양의 종류에 따 른 각 군의 분포를 살펴보면, 장액성 종양은 $\mathrm{A}$ 군 8 예, $\mathrm{B}$ 군 2 예, $\mathrm{C}$ 군 12예, D군 4예였고, 점액성 종양은 $\mathrm{A}$ 군 11예, $\mathrm{B}$ 군 4예, C군 13예였다. 종양의 종류에 따른 그룹 분포의 차이 는 없었다(p>0.05). 임상병기에 따른 각 군의 분포를 살펴 보면, $\mathrm{A}$ 군은 I기 12예, II기 5예, III기 2예였고, B군은 6예가 모두 I기였으며, C군은 I기 6예, II기 6예, III기 13예였고, D 군은 4예가 모두 III기였다. A군에서 D군으로 갈수록 병기 가 I기에서 III기로 진행되는 양상을 보였으며, 이는 통계학

Table 3. KAI-1 and survivin expression in western blot

\begin{tabular}{lcccc}
\hline & \multicolumn{2}{c}{ KAI-1 } & \multicolumn{2}{c}{ Survivin } \\
\cline { 2 - 5 } \cline { 3 - 4 } & Negative Positive & Negative Positive \\
\hline Histologic type & & & & \\
$\quad$ Serous carcinoma & 1 & 3 & 3 & 1 \\
Borderline serous carcinoma & 1 & 0 & 1 & 0 \\
Mucinous carcinoma & 2 & 1 & 3 & 0 \\
Bordeline mucinous carcinoma & 1 & 1 & 2 & 0 \\
Clinical stage & & & & \\
I & 2 & 2 & 4 & 0 \\
II & 1 & 0 & 1 & 0 \\
III & 2 & 3 & 4 & 1 \\
\hline Total & 5 & 5 & 9 & 1 \\
\hline
\end{tabular}

Table 4. Clinical stage according to KAI-1 and survivin group

\begin{tabular}{lrccc}
\hline & A & B & C & D \\
\hline I & 12 & 6 & 6 & 0 \\
II & 5 & 0 & 6 & 0 \\
III & 2 & 0 & 13 & 4 \\
\hline Total & 19 & 6 & 25 & 4 \\
\hline
\end{tabular}

group A $\rightarrow$ KAI-1: $51 \sim 100 \%$, survivin: $0 \sim 50 \%$ positive tumor cells, group B $\rightarrow$ KAI-1: $51 \sim 100 \%$, survivin: $51 \sim 100 \%$ positive tumor cells, group $\mathrm{C} \rightarrow \mathrm{KAI}-1: 0 \sim 50 \%$, survivin: $0 \sim 50 \%$ positive tumor cells, group D $\rightarrow$ KAI-1: $0 \sim 50 \%$, survivin: $51 \sim 100 \%$ positive tumor cells 
적으로 유의하였다 $(\mathrm{p}=0.0001) .4$ 개군에 대한 생존율 분석을 시행한 결과 $\mathrm{A}$ 군에서 $\mathrm{D}$ 군으로 갈수록 생존율이 감소하는 경향을 보였고, $\mathrm{D}$ 군이 $\mathrm{A}, \mathrm{B}$ 군에 비해 생존율이 통계학적으 로 유의하게 감소하였고 $(\mathrm{p}<0.001, \mathrm{p}=0.01), \mathrm{C}$ 군도 $\mathrm{A}$ 군에 비 해 통계학적으로 유의하게 생존율이 감소하였다 $(\mathrm{p}<0.01)$ (Table 4).

\section{고 찰}

난소의 상피성 종양은 세포의 종류에 따라 장액성, 점액 성 종양 등으로 구분하고 그 악성도에 따라 양성, 경계성, 악성으로 분류된다. 경계성과 악성 종양을 구분하는 것은 환자의 치료방법 설정 및 예후 판정에 중요한 일이지만 이 들을 구분하는 조직학적 진단은 주관적인 판독에 의존하기 때문에 개인 간의 진단의 차이가 있을 수 있어 종양의 정확 한 악성 등급을 정하고 예후를 예측하는 데 좀더 객관적인 방법이 요구된다. 난소 종양의 예후를 결정하는 데는 환자 의 나이, 병기, 조직학적 유형, 조직학적 분화도 및 치료방 법 등이 중요하다고 알려져 있으며, 그 외 여러 연구들에 의하면 암 유전자나 암 억제 유전자의 발현 등도 환자의 치료 및 예후에 영향을 미칠 수 있다고 보고되고 있으나, 아 직 임상적 이용은 제한적으로 이루어지고 있는 실정이다.

$\mathrm{KAI}-1$ 은 CD82로도 알려져 있는 유전자로 4 transmembrane domain을 가진 type III integral 단백으로 세포 표면 당 단백의 하나이다. $\mathrm{KAI}-1$ 은 정상 전립선 조직에 비해 전립선 종양에서는 $70 \%$ 가 감소하고, 전이가 된 경우는 거의 발현 되지 않는 것을 관찰하여 전립선암의 전이억제 유전자로 처음 알려지게 되었다(5). 최근 많은 연구들을 통하여 KAI-1 단백 발현 감소가 전립선암 뿐 아니라, 다른 암종에 서도 관찰되고 있는데, 암에서 KAI-1의 감소는 전이가 일어 날 가능성을 높이고, 임상경과가 나쁘고, 생존율도 감소하 는 것으로 알려져 있다(7 10).

상피성 난소 종양에서도 KAI-1에 대한 연구가 이루어지 고 있는데, 상피성 난소 종양에서 KAI-1에 대한 면역조직화 학 염색을 통해 난소 종양의 진행과 KAI-1 단백의 감소가 연관 관계가 있을 가능성이 제시되고 있을 뿐 아니라, $\mathrm{KAI}-1$ 단백이 감소된 예들이 생존율이 나쁘고, 특히 장액성 종양의 경우 다른 상피성 난소 종양보다 더욱 KAI-1과 생 존율이 밀접한 관계가 있다고 보고되고 있다 $(18,19)$. 본 연 구에서는 면역조직화학 염색 결과 임상병기가 높아질수록 KAI-1 단백이 발현되지 않는 경향을 보였고, 생존율도 강양 성으로 발현된 군이 양성과 음성으로 발현이 감소된 군에 비해 유의하게 생존율이 높아지는 경향을 보여, KAI-1 단백 발현이 예후 인자로 이용될 수 있는 가능성을 보여 주었다.
Survivin은 IAP 계열의 단백 중 하나로써 세포 주기 중 $\mathrm{G} 2-\mathrm{M}$ 기에 발현되어 유사분열 시 세포자멸사를 억제하는 한편, 세포자멸사 경로의 다양한 지점인 caspase 9, caspase 3 , caspase 7 등에서도 세포자멸사를 억제하는 작용을 가진 것으로 보고되고 있는데, 다른 IAP 단백들이 정상 성인 조 직에 광범위하게 존재하는 데 반해 survivin mRNA는 태아 조직에서만 존재하고 정상 성인에서는 태반과 흉선에만 존 재한다는 점이 다른 IAP 단백들과 다른 점이다(11 13). 폐 암, 대장암, 유방암 등 다양한 종류의 암종에서 강한 survivin 발현이 관찰되고 있다(14 16). 상피성 난소 종양에서 survivin을 예후 인자의 하나로 연구한 것은 매우 드문데, 투명세포 암종에서 survivin 발현이 관찰된다는 보고(20)가 있으나, 아직 난소암의 예후와 관련된 연구는 매우 부족한 상태이다. 본 연구의 경우 면역조직화학 염색은 10 예 $(18.5 \%)$ 가 강양성을 보였고, 28 예(51.9\%)가 양성으로 반응 하였으며, 16예(29.6\%)에서는 발현되지 않은 반면, western blot 결과 10 예의 상피성 난소 종양 중 survivin 단백은 1 예 의 장액성 선암종에서 발현되어 western blot 결과와 면역조 직화학 염색 결과가 큰 차이를 보였는데, 이는 western blot 을 시행할 수 있는 동결 조직이 10예로 표본수가 작았다는 점과 survivin에 대한 western blot의 민감도가 상대적으로 적기 때문에 발생한 것으로 보여, 향후 추가적인 연구가 필 요할 것으로 생각된다. 면역조직화학염색상 survivin 단백 발현과 상피성 난소 암종의 종류나 임상병기와는 통계학적 상관 관계가 없었다. 그러나, survivin 단백에 대한 생존곡선 분석상 생존율은 음성군, 양성군, 강양성군 순으로 감소하 는 경향을 보였고, 이 중 강양성으로 발현된 군은 음성인 군에 비해 통계학적으로 유의하게 생존율이 감소하는 $(\mathrm{p}=0.05)$ 결과를 보여 survivin 단백의 경우에도 앞으로 더 많은 연구가 필요하다고 생각된다.

KAI-1과 survivin 모두 p53에 의해 영향을 받을 가능성들 이 보고되고 있으나(21 23), 이는 암종마다 달라 아직 명 확한 결론을 내기는 힘들지만, KAI-1 단백과 survivin 단백 의 발현 양상을 함께 이용하여 평가할 경우, 암의 발생, 진 행, 전이 과정에서의 다양한 경로들을 종합적으로 평가할 수 있어 환자의 예후와 치료에 도움을 줄 수 있을 것으로 판단된다.

\section{결 론}

상피성 난소 종양 환자에서 임상병기가 높아질수록 KAI-1 단백 발현이 유의하게 감소되는 경향을 보였고, 생존 곡선 분석상 강양성으로 발현된 군이 양성과 음성으로 발 현이 감소된 군에 비해 생존율이 유의하게 높았다. Survivin 
단백의 경우, 강양성으로 발현된 군이 음성인 군에 비해 통 계학적으로 유의하게 생존율이 감소하여, KAI-1 단백과 survivin 단백의 발현 양상을 함께 평가하는 것이 환자의 예 후와 치료에 도움을 줄 수 있을 것으로 판단된다.

\section{REFERENCES}

1. Kurman RJ. Pathology of the female genital tract. In: Russel P. Surface epithelial - stromal tumors of the ovary. 4th ed. London: springer-Verlag, 1994:705-723.

2. Welcsh PL, King MC. BRCA1 and BRCA2 and the genetics of breast and ovarian cancer. Hum Mol Genet 2001;10(7): 705-713.

3. Berchuck A, Kohler MF, Boente MP, Rodriguez GC, Whitaker RS, Bast RC Jr. Growth regulation and transformation of ovarian epithelium. Cancer 1993;71:545-551.

4. Kim JW, Kwon DJ, Rha DJ, Lee JM, Kim DH, Namkoong SE, Kim SJ. Mutations of the p53 tumor suppressor gene in human epithelial ovarian cancer. J Korean Cancer Assoc 1994; 26:296-303.

5. Dong JT, Lamb PW, Rinker-Schaeffer CW. KAI 1, a metastasis suppressor gene for prostate cancer on human chromosome 11p11.2. Science 1995;268:884-886.

6. Helmer ME, Mannion BA, Berditchevski F. Association of TM4SF proteins with intrins: relevance to cancer. Biochim Biophys Acta 1996;7:1287(2-3):67-71.

7. Guo X, Friess H, Graber HU, Kashiwagi M, Zimmermmann A, Kore M, Buchler MW. KAI 1 expression is up-regulated in early pancreatic cancer and decreased in the presence of metastasis. Cancer Res 1996;56(21):4876-4880.

8. Adachi M, Taki T, Ieki Y, Huang CI, Higashiyama M, Miyake M. Correlation of KAI 1/CD 82 gene expression with good prognosis in patients with non-small cell lung cancer. Cancer Res 1996;56(8):1751-1755.

9. Yu Y, Yang JL, Markovic B, Jackson P, Yardley G, Barret J, Russel PJ. Loss of KAI 1 messenger RNA expression in both high grade and invasive human bladder cancers. Clin Cancer Res 1997;3(7):1045-1049.

10. Huang CI, Kohno N, Ogawa E, Adachi M, Taki T, Miyake M. Correlation of reduction in MRP-1/CD9 and KAI1/CD82 expression with recurrence in breast cancer patients. Am J Pathol 1998;153(3):973-983.

11. Ambrosini G, Adida C, Altieri DC. A novel anti-apoptosis gene, survivin, expressed in cancer and lymphoma. Nat Med 1997;3:917-921.
12. LaCasse E, Baird CS, Kormeluk RG, Mackenzie AE. The inhibitors of apoptosis (IAPs) and their emerging role in cancer. Oncogene 1998;17:3247-3259.

13. Tamm I, Wang Y, Sauaville E, Scudierro DA, Vigna N, Oltersdorf T, Reed JC. IAP-family protein surviving inhibits caspase activity and apoptosis induced by Fas (CD 95) bax, caspases and anticancer drug. Cancer Res 1998;58:5315-5320.

14. Kawasaki H, Altieri DC, Lu CD, Toyada M, Tanigawa N. Inhibition of apoptosis by survivin predicts shorter survival rates in colorectal cancer. Cancer Res 1998;58:5071-5074.

15. Monzo M, Rosell R, Felip E, Astudillo J, Sanchez JJ, Maestre J, Martin C, Font A, Barnadas A, Abad A. A novel antiapoptosis gene: reexpression of survivin messenger RNA as a prognosis marker in non small cell lung cancers. J Clin Oncol 1999;17:2100-2104.

16. Tanaka $\mathrm{K}$, Iwamoto $\mathrm{S}$, Gon $\mathrm{G}$, Nohara $\mathrm{T}$, Iwamoto $\mathrm{M}$, Tanigawa N. Expression of survivin and its relationship to loss of apoptosis in breast carcinoma. Clin Cancer Res 2000;6:127134.

17. International Federation of Gynecology and Obstetrics Cancer Committee. Staging announcement. Staging of Gynecologic malignancies. Chicago, 1994, Society of Gynecologic Oncologist.

18. Liu Fs, Dong JT, Chen JT, Hsieh YT, Ho ES, Hung MJ. Frequent down-regulation and lack of mutation of the KAI1 metastasis suppressor gene in epithelial ovarian carcinoma. Gynecol Oncol 2000;78:10-15.

19. Schindl M, Birmer P, Bretenecker G, Oberhuber G. Downregulation of KAI1 metastsis suppressor protein is associated with a dismal prognosis in epithelial ovarian cancer. Gynecol Oncol 2001;83:244-248.

20. Yoshida H, Ishiko O, Sumi T, Matsumoto Y, Ogita S. Survivin, bcl-2 and matrix metalloproteinase-2 enhance progression of clear cell - and serous-type ovarian carcinomas. Int $\mathbf{J}$ Oncol 2001;19(3):537-542.

21. Mashimo T, Watabe M, Hirota S, Hosobe S, Miura K, Tegtmeyer PJ, Rinker-Schaeffer $\mathrm{CW}$, Watabe $\mathrm{K}$. The expression of the KAI1 gene, a tumor metastasis suppressor, is directly activated by p53. Proc Natl Acad Sci USA 1998;95:1130711311.

22. Dong J, Suzuki H, Pin SS, Bova GS, Schalken JA, Isaacs WB, Barret JC, Isaacs JT. Down-regulation of the KAI1 metastasis suppressor protein KAI1 on prognosis of human prostatic cancer infrequently involves gene mutation or allelic loss. Cancer Res 1996;56:4387-4390.

23. Lu CD, Altieri DC, Tanigawa N. Expression of a novel antiapoptosis gene, survivin, correlated with tumor cell apoptosis and p53 accumulation in gastric carcinomas. Cancer Res 1998; 58:1808-1812. 